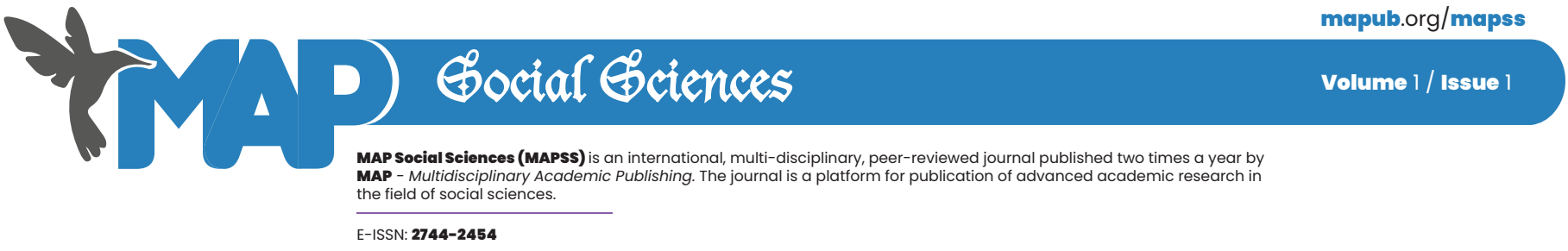

ORIGINAL RESEARCH PAPER

\title{
TO SPEAK OR NOT TO SPEAK? THEORETICAL FRAMEWORK OF WILLNGNESS TO COMMUNICATE
}

\author{
Emina Kahrimanovié (i) \\ International Burch University, Sarajevo, Bosnia and Herzegovina
}

Correspondence concerning this article should be addressed to Emina Kahrimanović, International Burch University, Sarajevo, Bosnia and Herzegovina. E-mail:

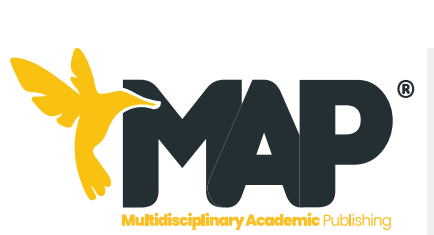

MAP SOCIAL SCIENCES

Volume 1/ Issue

ISSN: 2744-2454/ @ 2021 The Authors. Published by MAP - Multidisciplinary

Academic Publishing.

Article Submitted: 30 July 202 Article Accepted: 18 August 202 Article Published: 03 September 2021

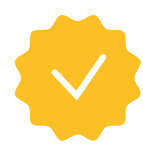

Publisher's Note: MAP stays neutral with regard to jurisdictional claims in published

\section{ABSTRACT}

The decision of a speaker whether to communicate in a specific situation or not, assuming they have the right to choose, has been identified in the current literature as the speaker's willingness to communicate (WTC). In recent times, with the communication becoming the backbone of successful professional and private lives and the role of world languages ever increasing, the importance of willingness to communicate in one of the world languages (English, French, German, etc.) comes to the fore. Therefore, many authors have embarked on a journey to prove why willingness to communicate shall be put under the spotlight and why should language instructors set the engendering of WTC as one of the main aims of language instruction. Among the abundance of reasons, it is often argued that willingness to communicate may facilitate language learning itself. This paper represents a theoretical framework of research conducted on the subject of willingness to communicate over the past several decades, with emphasis on WTC in language learning.

Keywords: willingness to communicate, unwillingness to communicate, variables influencing WTC 


\section{Gocial Geiences \\ by MAP - Multidisciplinary Academic Publishing \\ TO SPEAK OR NOT TO SPEAK? THEORETICAL FRAMEWORK OF WILLINGNESS TO COMMUNICATE \\ Emina Kahrimanović}

\section{Introduction}

Global village. It is a term used nowadays to describe the world in which people come closer together through increased contact and communication, creating a single global system in which developments in one part of the world influence individuals and communities elsewhere in the world. This process of globalization has been the major driver of change in societies, and it all starts with - communication. Therefore, in order to become a part of this village, the willingness to communicate (WTC) with others around us has become somewhat of an unwritten rule. However, being willing to communicate does not necessarily open all the doors. One of the key characteristics of this global world is prevalence of several major world languages in communication, such as English, French, and Spanish. Therefore, learning one of those languages is of utmost importance.

The term willingness to communicate first appeared in 1992, when McCroskey (1992) coined it as a reference to a person who chooses to approach or avoid communication under certain circumstances, assuming that they can choose freely whether to communicate or not. It is especially important in the field of language learning. Many authors have hypothesized and confirmed that language learners with high communicative disposition will actively seek opportunities to engage in communicative behavior, thus improving communicative competence and achieving better overall learning outcomes (Bećirović et. al, 2021).

This article explains the concepts of willingness to communicate and unwillingness to communicate and provides an overview of variables influencing WTC in language learners. Finally, specific advice on how to engender WTC in language learners is provided, which may help teachers and policy makers create curricula that prepares the students for the society of the present.

\section{Discussion}

\section{Unwillingness to communicate}

The harbinger of the concept of willingness to communicate is the concept of unwillingness to communicate, introduced by Burgoon (1976). Burgoon (1976) stated that individuals who are reserved towards communication tend to be unwilling to communicate. Unwillingness to communicate is described as a chronic tendency of an individual to avoid communication and to view the communication situation as something that is relatively unrewarding (Burgoon, 1976).

Some of the most prominent sociological and psychological variables that are said to have an impact on unwillingness to communicate are communication apprehension, low self-esteem, lack of communicative competence, anomia, alienation, introversion, etc. Some of the factors will be described in more detail below.

Communication apprehension. The ability to communicate is generally described as the trait that defines us as human beings and distinguishes us from the rest of the environment we live in. The importance of communication process can never be overemphasized (Bećirović et al., 2020). Effective communication is crucial for being a valuable member of a society. However, communication itself is not enough. We must understand what others are saying in order to make use of the information we receive. Unfortunately, sometimes barriers exist that hinder our understanding of others. Communication apprehension is one of them (Warner, 1997).

Communication apprehension is a broad term that refers to an individual's fear or anxiety that is associated with real or expected communication with another individual or individuals (McCroskey, 2001). Many factors influence communication anxiety to different extents. Some of those factors are the degree of evaluation, the perceived relationship between the speaker and their audience, the feeling of prominence of the speaker, degree of unpredictability of the situation, memories, communication skills that the speaker possesses or lacks, etc.

Regarding the degree of evaluation, it is well known in teaching practice that students feel more relaxed and confident when they are not being evaluated and that they often get confused and anxious when it comes to evaluation. The more serious and important the evaluation is, their anxiety increases and thus affects their WTC in a negative way (Ahmetović, Bećirović \& Dubravac, 2020). Furthermore, the relationship between the language learner and the person they are speaking to is also very important. Results of many previous studies such as the one conducted by Macintyre et al. (1998), as well as the present study, indicate that language learners are most willing to communicate with people whom they feel close connection with 


\section{Gociar Geiences \\ by MAP - Multidisciplinary Academic Publishing \\ TO SPEAK OR NOT TO SPEAK? THEORETICAL FRAMEWORK OF WILLINGNESS TO COMMUNICATE \\ Emina Kahrimanović}

and people who they encounter frequently. Consequently, WTC is lower in cases of weak relationships between the learner and the person or persons they speak to. These two are probably one of the most frequent causes of communication anxiety.

Furthermore, a speaker is likely to suffer from communication anxiety if their perception is that a lot is at stake in a certain communication act, if they feel inferior in relation to their audience, if they are not prominent by nature, if they perceive the situation to be too unpredictable, if they remember prior experiences of communicative acts, whether failures or successes, and if they conclude that they lack certain communication skills required by the given situation (Dervić \& Bećirović, 2020).

Many methods of treatment of communication anxiety exist. The study by Warner (1997) provides a thorough explanation of a method that is found to be the most effective and efficient. In the study, Warner states that "systematic desensitization, also known as reciprocal inhibition, is based on the idea that when one reflex dominates another, the symptoms from the dominated reflex disappear" (Warner, 1997, p. 27).

The initial reflex of speakers who suffer from communication anxiety is to develop symptoms of fear and anxiety (Ahmetović, Bećirović \& Dubravac, 2020). However, through systematic desensitization that reflex is substituted with the reflex of relaxation. Once the speaker makes the reflex of relaxation automatic, the initially dominant reflex of fear becomes the dominated reflex that disappears (Warner, 1997).

Self-esteem. In general, it is considered that people with low self-esteem have developed fewer communication skills than people with high self-esteem. Also, studies found that they are more susceptible to conformity and persuasion, as well as defensive behaviors. One of the possible explanations for these findings is that people with low self-esteem usually do not have confidence in their own opinion and tend to conform to the opinion of the majority. Also, other people easily persuade them into believing the opposite of what they initially believed.

Brown (2000) defined self-esteem as the most pervasive aspect of any human behavior. In 2002, Richards and Schmidt (2002) conceptualized self-esteem as a concept describing an individual's judgment of their own worth on the basis of their perceived feeling of efficacy. In L2 contexts, self-esteem is often positively correlated with achievement - the higher L2 achievement is, the higher learner's self-esteem is.

Anomia. Anomia is an equivalent of a type of neurosis called anomie. Anomie occurs when an individual's bonds with society are broken, resulting in fragmentation of social identity. The instability of individuals in this case results from the lack of purpose in an individual's life.

Emile Durkheim (1983) was the first to introduce the term anomie, conceptualized as a lack of norms, and he characterized the modern individual as insufficiently integrated into society. According to Durkheim (1983), when these bonds weaken, individuals are left to exist on their own and this breakdown of moral guidance leads to deviance, social unrest, unhappiness, and stress.

Anomics fail to internalize societal norms, they develop insecurity, powerlessness, social isolation, and they perceive life as valueless and meaningless (Burgoon, 1976). The negative attitudes towards communication lead to the lack of trust and eventually withdrawal from any form of communication.

Introversion. According to dictionary definition, introversion is the state of being predominantly interested in one's own mental self. Introverts are generally perceived as shy, timid, reserved towards other people. They prefer reflection of one's own personality over communication with other people and are likely to engage in solitary activities like reading and writing.

Introversion is often considered a counterpart of shyness. However, that view is entirely mistaken. Introverts do not necessarily feel anxious about communication like shy people do. They simply avoid communication as they find it to be a process that wastes their mental and physical energy. For these reasons, introversion is more related to realistic and investigative occupations and extroversion is more related to social and enterprising occupations (Broday and Sedgwick, 1991).

Another important point to mention is that introverted persons do not necessarily resent every form of communication. In specific situations, such as when they are genuinely interested in the topic 


\section{Gocial Geiences \\ by MAP - Multidisciplinary Academic Publishing \\ TO SPEAK OR NOT TO SPEAK? THEORETICAL FRAMEWORK OF WILLINGNESS TO COMMUNICATE \\ Emina Kahrimanović}

and when they feel they are confident enough to participate in communication, there is a chance that they will not avoid communication. It is all a matter of their interest and their judgment whether a specific topic or a specific person is worth the energy they would put into communication (Broday and Sedgwick, 1991).

\section{Heuristic Model of Variables Influencing WTC}

Despite the fact that willingness to communicate has mostly been reduced down to a traitlike variable, Maclntyre, Clement, Dörnyei, and Noels (1998) argued that it should not necessarily be limited within the borders of such description. In their view, willingness to communicate is also a situational variable that comprises some impermanent and some permanent variables (Zarrinabadi and Abdi, 2011). In the context of second language (L2) learning, which will be specifically addressed in this paper, WTC was described as "a readiness to enter into discourse at a particular time with a specific person or persons, using a L2" (Maclntyre, Clement, Dörnyei, Noels, 1998, p. 547).

Additionally, Maclntyre et al. (1998) established a heuristic model of those variables that are believed to have the most significant effect on willingness to communicate. This pyramid model is presented in Figure 1 and has six layers. The first three layers comprise those impermanent variables, the ones specific to a certain situation or context, whereas the remaining six layers comprise those permanent variables, those with an abiding influence on willingness to communicate. The pyramid consists of twelve constructs in total.

It should be kept in mind that the competence in the target language is not the only important predictor of target language use (Rizvić \& Bećirović, 2017). Just knowing how good the student's command of the target language is and what language skills and systems the student has acquired is not enough to conclude that this particular student will be willing to contribute to communication at a certain point. This communication rather depends on a complex mixture of different psychological, social and educational factors as well, in addition to the linguistic knowledge. This heuristic model shows some of the interactions between these different factors (Mystkowska-Wiertelak \& Pawlak, 2016). Observing from the first to the last layers, it is possible to note how the focus shifts from the immediate, impermanent influences to those more permanent ones. (Modirkhameneh and Firouzmand, 2014).

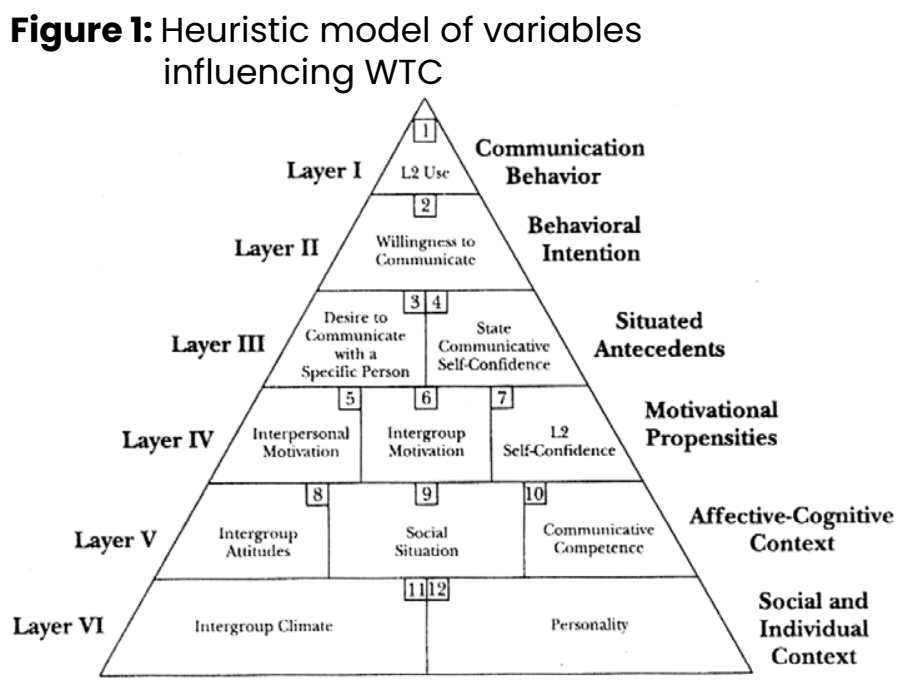

Source: P.D. MacIntyre, R. Clement, Z. Dörnyei \& K. Noels, 1998

The first layer in the pyramid is the actual use of the second or foreign language, including activities that are based on authentic material and information. In other words, the use of the $L 2$ is marked as communication behavior of the speaker. Second language can be used in many different ways in a language classroom. In terms of language skills, language can be used through reading authentic texts such as newspaper articles, letters, emails, etc. in writing, language instructors can also ask the students to write a letter to a friend or describe an event from their past, thus producing authentic information. Similar activities can be done in the speaking part, where students can engage in role-play activities, for instance. Through all these activities, language learners exhibit their communication behaviors and enable the language instructor to create a profile for each and every student.

In the next, second layer, willingness to communicate is presented as the behavioral intention of the L2 speaker. These top layers reflect the intention of a speaker to communicate with a specific person at a specific time. Therefore, this is the logical continuation of the sequence. Since all learners have certain communication behaviors - ways in which they communicate - now it is their behavioral intention that determines whether they want to communicate or not, and this intention differs 


\section{Gocial Geiences \\ by MAP - Multidisciplinary Academic Publishing \\ TO SPEAK OR NOT TO SPEAK? THEORETICAL FRAMEWORK OF WILLINGNESS TO COMMUNICATE \\ Emina Kahrimanović}

from one person to another and from one situation to another.

The third layer is slightly more complicated and it comprises two constructs: the first one being the desire to communicate with a specific person and the second one being the state communicative self-confidence as antecedents of communication in L2, where state communicative self-confidence depicts how an individual feels regarding their competence to communicate in a certain language in a certain situation, with a specific collocutor. It was stated by Maclntyre et al. (1998) that people are more willing to communicate with the people who they find physically closer to them, those who they have the opportunity to encounter more often, those people who they find to be physically attractive, or in simple terms with people who they consider similar to themselves in many different ways.

Variables in the remaining three layers of the pyramid have an enduring influence on WTC and are mostly predictable in almost every situation. They strive to explain why one individual would choose to communicate in a situation when another one would choose not to (Compton, 2007).
The fourth layer of the pyramid presents the motivational propensities - interpersonal motivation, intergroup motivation, and L2 self-confidence. In fact, interpersonal motivation and intergroup motivation are the basic factors that affect individual's desire to communicate with specific persons (Zarrinabadi and Abdi, 2011). Interpersonal motivation is defined as motivation directed towards other people, and it is actually the way in which people see themselves in comparison with others - for example, this concept can be used as a psychological answer in case when a learner asks themselves why their classmates are behaving in a strange way around them. Intergroup motivation is a concept similar to interpersonal motivation, only expanded to cover group contexts (Bećirović \& Hurić - Bećirović, 2017). Regarding the L2 self-confidence, this concept was covered previously in the text.

Although Macintyre and Charos (1996) found that motivation did not have a significant impact on WTC, some studies in specific contexts such as Hashimoto's (2002) in Japan proved opposite results in some replications. Three motivational propensities that influence WTC according to MacIntyre et al. (1998) are described in Table l, where each motivational propensity is linked to individual's communication intention - whether an individual wants to take control over a group or affiliate with a group.

Table 1: Description of motivational propensities (adapted from Compton, 2007)

\begin{tabular}{|c|c|c|}
\hline Motivational Propensities & Purpose & Description \\
\hline \multirow{2}{*}{ Interpersonal motivation } & Control & $\begin{array}{l}\text { Motivation for communication is to exercise social role and maintain } \\
\text { control over a certain task. }\end{array}$ \\
\hline & Affiliation & Motivation for communication is to establish a relationship with others. \\
\hline \multirow{2}{*}{ Inter-group motivation } & Control & $\begin{array}{l}\text { Motivation for communication is to maintain and reinforce social posi- } \\
\text { tions in a group setting. }\end{array}$ \\
\hline & Affiliation & $\begin{array}{l}\text { Motivation for communication is to establish or maintain rapport with } \\
\text { members in a group. }\end{array}$ \\
\hline \multirow{2}{*}{ L2 confidence } & Competence & L2 confidence increases if mastery of L2 skills is high and vice versa. \\
\hline & Anxiety & $\begin{array}{l}\text { L2 confidence decreases if one experiences high levels of discomfort } \\
\text { when using L2 and vice versa. }\end{array}$ \\
\hline
\end{tabular}




\section{Gocial Geiences \\ by MAP - Multidisciplinary Academic Publishing \\ TO SPEAK OR NOT TO SPEAK? THEORETICAL FRAMEWORK OF WILLINGNESS TO COMMUNICATE \\ Emina Kahrimanović}

In the fifth layer of the model, Macintyre et al. (1998) presented variables that are found in the affective and cognitive context, including intergroup attitude, social situation, and communicative competence. There are some quite firm links between these variables and the variables mentioned in the previous layers. For instance, high levels of motivation to learn L2 in order to communicate and integrate within a group can actually promote positive attitudes towards that group and thus increase WTC. Willingness to communicate also increases when an individual is familiar with the social context and when an individual feels as their linguistic or sociocultural competence is sufficient for communication.

Finally, the sixth layer of the pyramid is the layer of social and individual context - social context comprising the intergroup climate and individual context comprising personality variables. Thanks to this situational perspective on WTC researchers managed to draw a conclusion that willingness to communicate is also contingent on certain situational variables, not only the personality ones (Baker and Maclntyre 2000; Clement et al. 2003; Maclntyre et al. 2001). Maclntyre et al. (1998) explain that L2 societies with relative socioeconomic power have a high ethno-linguistic vitality that encourages the use of L2. Compton (2007, p. 3) explains it as "the adaptation to the host culture would likely correspond with the benefits including social acceptance and economic advancement".

When it comes to individual differences, researchers believe that the "big five" traits (extraversion, agreeableness, conscientiousness, emotional stability, and openness to experience) contribute to the motivation for language learning willingness to communicate (Goldberg, 1993; Maclntyre \& Charos, 1996). Additionally, they note that individual differences can also be explained in broader societal terms in that certain groups may have similar traits. For instance, they cite Aida (1994) who wrote in their study how an average American language learner is more likely to be extraverted than an average Japanese learner.

Willingness to communicate in the first and second language

Originally, the concept of WTC was hypothesized as a personality trait that accounts for individual differences in communication in first language (LI) contexts (McCroskey \& Baer, 1985). Hence, WTC in Ll context was first described through personality traits before it moved toward situational variables. Willingness to communicate in the first language largely depends on underlying traits that make up an individual's own personality. Those traits are openness, conscientiousness, extraversion, agreeableness, and neuroticism. Their facets as identified by Costa and McCrae (1992) are presented in Figure 2 .

\section{Figure 2: The "Big Five" personality traits}

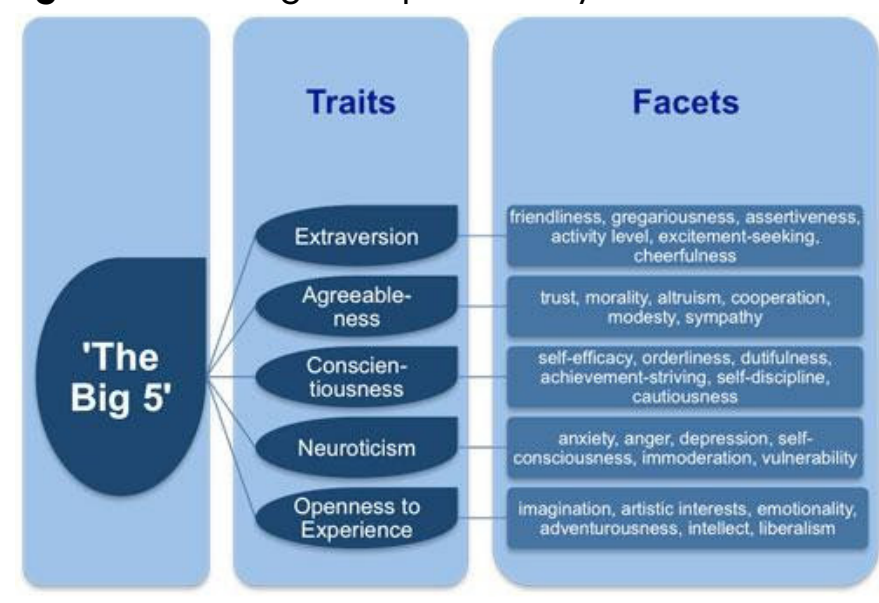

Source: Costa \& McCrae, 1992

Openness includes characteristics such as insightfulness, imagination, a wide range of interests, etc. Extraverted persons like to engage in interaction with other people and are generally energetic, communicative and assertive. Individuals that possess the agreeableness trait are friendly, cooperative and compassionate, mostly kind and sympathetic. Neuroticism refers to emotional stability and the degree of negative emotions. Individuals that exert high levels of openness, extraversion, conscientiousness and agreeableness and low levels of neuroticism are considered to be more willing to communicate in Ll. In fact, the Big Five personality dimensions test is frequently used by human resources professionals when hiring employees for certain positions that need to be taken by communicative people.

Studies found that WTC contingent on personality traits may potentially affect people in all communication settings in Ll contexts. However, Maclntyre (1994) proposed that researchers combine personality traits with situational ones in order to measure WTC in L2 settings. His suggestion resulted in the heuristic model of transient and enduring influences on WTC and that model has a 


\section{Gocial Geiences \\ by MAP - Multidisciplinary Academic Publishing \\ TO SPEAK OR NOT TO SPEAK? THEORETICAL FRAMEWORK OF WILLINGNESS TO COMMUNICATE \\ Emina Kahrimanović}

significant impact on WTC research in the second language.

\section{Engendering WTC}

Regardless of all the factors that are found to influence willingness to communicate, from the very beginning of language instruction some students are willing to communicate and some are not, depending to a large extent on their personality, as well as on the conditions in a specific communication context both in physical sense and in terms of collocutors. However, quality input and output are of great importance for successful L2 learning. Considering this, it can be said that the endmost goal of L2 learning should be to increase the willingness to communicate in language learners (Maclntyre, Clément, Dörnyei \& Noels, 1998).

Some studies found that willingness to communicate can best be engendered through the inclusion of technologies in the language learning process (Yaman \& Bećirović, 2016) in approaches such as Computer Assisted Language Learning (CALL). Chotipaktanasook (2014) emphasized the importance of technologies in language learning process, highlighting the need for language educators to adapt to the conditions of the $21^{\text {st }}$ century. The role of certain technological devices in language instruction has not been fully elaborated on yet, but some technologies, especially those related to social media, "have been the central concern of a number of educators and teachers and been welcomed as indispensable tools to be utilized for educational purposes" (Chotipaktanasook, 2014, p. 17).

It has already been stated that students need both input and output in order to learn an L2. The ultimate pedagogical aim of language instructors should be to enhance the students' willingness to communicate in L2. They must not only be able to use the second or foreign language, but they also must be willing to engage in L2 communication (Dörnyei, 2005). Consequently, language instruction aimed at improving communicative competence should be combined with activities aimed at enhancing willingness to communicate in general (Chotipaktanasook, 2014).

Willingness to communicate is seen by many as the final step before the use of second or foreign language in real world. Thus, when evaluating language instruction programs great impor- tance should be given to the aspects of the program that deal with engendering WTC in students. Many researchers have proposed different ways of enhancing WTC.

Noon-ura (2008) stated that students should be familiar with the target language culture in order to develop interest in a certain language, which will in turn be beneficial when it comes to engendering their WTC in a certain target language. Furthermore, a safe environment where students do not feel anxious and afraid to speak is also one of the preconditions for high WTC. Students should have sufficient knowledge of the target language and they should be allowed to work in pairs or small groups before working with the entire class, as this contributes to lower levels of anxiety and "stage fright" (Chotipaktanasook, 2014).

Characteristics of teachers can also have a huge impact on willingness to communicate. When teachers give constructive feedback to students, when they prompt students to do better and when they do all of that in an anxiety-free environment, then students' WTC can be enhanced (Pattapong, 2010). Cao (2006) stated that teachers can also intentionally choose activities that foster willingness to communicate and motivate students to engage in L2 communication. According to Dörnyei and Kormos (2000), teachers must work on developing positive attitudes of students towards activities and tasks they are expected to complete.

Khatibi and Zakeri $(2014$, p. 7$)$ stated that in order to make students willing to communicate in an L2 teachers ought to "provide the factors facilitating WTC as much as possible, instead of focusing on one factor at the expense of other facilitating factors". Further studies showed that some of the areas that teachers should take into consideration are cultivating group cohesiveness, lowering anxiety, creating an interesting and relevant lesson plan, instilling an international posture in students, and increasing motivation (Mašić et al, 2020; $\mathrm{Au}^{-}$ brey, 2010). Of the aforementioned areas, motivation is usually the most important and therefore the following section will deal with findings regarding motivation in language learning.

\section{Gardner's Socio-Educational Model}

In 1959, Gardner and Lambert (1959) developed an approach to motivation that established a distinction between integrative motivation and 


\section{Gocial Geiences \\ by MAP - Multidisciplinary Academic Publishing \\ TO SPEAK OR NOT TO SPEAK? THEORETICAL FRAMEWORK OF WILLINGNESS TO COMMUNICATE \\ Emina Kahrimanović}

instrumental motivation. According to their approach, integrative motivation encompasses all the positive attitudes that a learner has regarding the target language culture and individual's willingness to become a part of the target language community. Instrumental motivation is seen as a type of motivation that is evoked by practical reasons behind learning a foreign language, such as employment, social recognition, etc.

Many years later, Gardner (1985) established a socio-educational model of motivation in second language learning. It concerns the role of a range of differences in the process of L2 learning. According to this model, integrativeness or the desire to become a part of the target language community and attitudes towards the learning situation contribute to learner's motivation. Gardner (2001) later extended this integrativeness concept to encompass the individual's openness to other cultural groups, as well as respect for them, and different ways of life, without being necessarily driven to fully integrate into the target community (Peng, 2007).

Figure 3: Gardner's socio-educational model

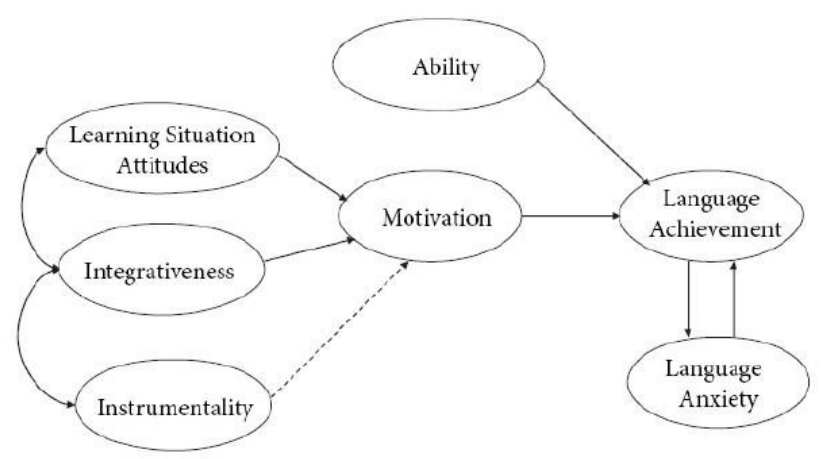

Source: Gardner (2001)

As can be seen from the Figure 3, integrativeness together with instrumentality or instrumental motivation, as well as with attitudes towards the learning situation, affects learner's motivation. Another emphasized aspect is the language ability of learners. Also noticeable is the mutual effect that language achievement and language anxiety have on each other.

In order to assess these variables, Gardner developed the Attitude/Motivation Test Battery (AMTB), whose adaptations have been used by many researchers such as Baker \& Maclntyre
(2000), Gardner, Lalonde, Moorcroft \& Evers (1987), Gardner \& Maclntyre (1993), Tremblay \& Gardner (1995), etc. The AMTB comprises more than 130 items whose reliability and validity are in the satisfactory range.

Gardner's AMTB consists of 11 "subtests" grouped into five categories (Gardner, 2001). Three of those subtests have been mentioned above (integrativeness, attitudes toward the learning situation, and motivation). The remaining two are instrumental orientation, referring to the instrumental motivation for learning the language for practical reasons, and language anxiety, involving anxiety during the times when L2 is supposed to be used in communication.

Many researchers were influenced by this socio-educational model proposed by Gardner. Maclntyre combined his model with Gardner's in order to investigate the vital variables in L2 WTC, concluding that WTC significantly influences the frequency of communication in the second language, and that in turn the WTC was influenced by perceived L2 competence, motivation, and anxiety (Hashimoto, 2002). In review of this model, Peng (2007, p. 6) went on to conclude that "this model suggests that learners who are attitudinally affiliated with the $L 2$ community will be more motivated to persevere in learning the $L 2$ in both formal and informal situations". However, Gardner (2001) kept the reservation regarding the limits of the applicability of this model. Despite the fact that the proposed model focuses on motivation, primarily integrative, Gardner (2001) goes on to suggest that there might be some other factors that directly influence language achievement, proposing among others the language learning strategies, language anxiety, and self-confidence in language learning (Gardner, 2001).

\section{Conclusion}

Considering how important the concept of willingness to communicate is in the process of integrating into the society and learning another language, it is crucial for language instructors to understand the range of variables that might exert some influence on WTC, including both situational and personal variables. With that knowledge, it is easier for them to set pedagogical aims and organize their classroom as to utilize the willingness to communicate to its maximum capacity for facilitating language learning process (Kim, 2004). It is 


\section{Gocial Geiences \\ by MAP - Multidisciplinary Academic Publishing \\ TO SPEAK OR NOT TO SPEAK? THEORETICAL FRAMEWORK OF WILLINGNESS TO COMMUNICATE \\ Emina Kahrimanović}

very important to design language classes so that they contain a lot of authentic information, a lot of opportunities for students to communicate, and a lot of activities that will require all of them to do so. Students with high WTC are more likely to use L2 in authentic communication contexts and function as autonomous learners by making independent efforts to learn language. Furthermore, students with high WTC will have more opportunities to use language and become involved in learning activities both inside and outside classrooms. Consequently, it could be suggested that such learners achieve more in language classes.

Nowadays it is not only of educational, but also of pragmatic importance to learn at least one world language. Considering all the doors that the knowledge of even one world language opens to those who can speak it, learning it is definitely worth the effort (Sinanović \& Bećirović, 2016).

\section{References}

Ahmetović, E., Bećirović, S., \& Dubravac, V. (2020). Motivation, anxiety and students' performance. European Journal of Contemporary Education, 9(2), 271-289. https://doi.org/10.13187/ ejced.2020.2.271

Aubrey, S. (2010). Influences on Japanese students' willingness to communicate across three different sized EFL classes (Master's thesis). Asian EFL Journal. Retrieved from www.asian-efl-journal. com/Thesis/Thesis-Aubrey.pdf

Baker, S. C. \& Macintyre, P. D. (2000).The role of gender and immersion in communication and second language orientations. Language Learning, 50(2), 311-341. https://doi.org/10.111/0023-8333.00119

Bećirović, S., Brdarević-Čeljo, A., \& Polz, E. (2021). Exploring the relationship between language learning strategies, academic achievement, grade level, and gender. Journal of Language and Education, 7(2), 93-106. https://doi.org/10.17323/ jle.2021.10771

Bećirović, S., Dubravac, V., \& Laličić, A. (2020). The interconnection between vocabulary learning strategies and EFL learning outcomes. European Journal of Education Studies, 7(12), 106-129. https:// doi.org/10.46827/ejes.v7i12.3402
Bećirović S., Hurić - Bećirović, R., (2017), The role of age in students' motivation and achievement in learning English as a second language, JoLIE - Journal of Linguistic and Intercultural Education, 10(1), 23-36. DOI: https://doi.org/10.29302/ jolie.2017.10.1.2

Broday, S., \& Sedgewick, C. (1991). The relationship between the SCll introversion-extroversion scale and occupational scales. SAGE Journals, 51(1), 175-179. https://doi.org/10.1177/0013164491511017

Brown, J. D. (2001). Using surveys in language programs. Cambridge: Cambridge University Press.

Burgoon, J. K. (1976). The unwillingness-to-communicate scale: Development and validation. Communication Monographs, 43, 60-69. https://doi.org/10.1080/03637757609375916

Cao, Y. (2006). Temporal fluctuations in situational willingness to communicate in a second language classroom. New Zealand Studies in Applied Linguistics, 12(2), 1-16.

Chotipaktanasook, N. (2014). Using social media to improve learners' willingness to communicate in English. Paper presented at the Tokyo International Conference on Social Sciences (TICSS 2014), Tokyo, Japan, 17-19 December 2014.

Clément, R., Baker, S. C., \& Maclntyre, P. D. (2003). Willingness to communicate in a second language: The effects of context, norms, and vitality. Journal of Language and Social Psychology, 22, 190209. https://doi.org/10.1177/0261927X03022002003

Compton, L. (2007). The impact of content and context on international teaching assistants' willingness to communicate in the language classroom. Teaching English as a Second or Foreign Language, 10(4). Retrieved from http://tesl-ej.org/ wordpress/

Costa, P. T. Jr., \& McRae, R. R. (1992). Revised NEO Personality Inventory (NEO-PI-R) and NEO Five-Factor Inventory (NEO-FFI) professional manual. Odessa, Florida: Psychological Assessment Resources, Inc.

Dervić, M., \& Bećirović, S. (2020). Prerogative of the Lexical Approach in Communicative Language Teaching, European Journal of Education Studies, 7(3), 1-13. doi: 10.5281/zenodo.3748039 


\section{Gocial Geiences \\ by MAP - Multidisciplinary Academic Publishing \\ TO SPEAK OR NOT TO SPEAK? THEORETICAL FRAMEWORK OF WILLINGNESS TO COMMUNICATE \\ Emina Kahrimanović}

Dörnyei, z. (2005). The psychology of language learner. Hillsdale, NJ.: Lawrence Erlbaum Associates.

Dörnyei, Z., \& Kormos, J. (2000). The role of individual and social variables in oral task performance. Language Teaching Research, 4(3), 275300. doi:10.1177/136216880000400305

Durkheim, E. (1983). Pragmatism and sociology. Cambridge University Press.

Gardner, R. C. (1985). Social psychology and second language learning: The role of attitudes and motivation. London: Edward Arnold.

Gardner, R. C. (2001). Integrative motivation and second language acquisition. In Z. Dörnyei \& R. Schmidt (Eds.), Motivation and second language acquisition (Technical Report \#23, pp. 422-459). Honolulu: University of Hawaii, Second Language Teaching and Curriculum Center.

Gardner, R. C., \& Macintyre, P. D. (1993). On the measurement of affective variables in second language learning. Language Learning, 43(2), 157194. https://doi.org/10.111/j.1467-1770.1992.tb00714.x

Gardner, R. C., Lalonde, R. N., Moorcroft, R.t \& Evers, F. T. (1987). Second language attrition: The role of motivation and use. Journal of Language and Social Psychology, 6, 29-47. https://doi. org/10.1177/0261927X8700600102

Goldberg, Lewis. (1993). The structure of phenotypic personality traits. American Psychologist. 48. 26-34. https://doi.org/10.1037/0003-066X.48.1.26

Hashimoto, Y. (2002) Motivation and willingness to communicate as predictors of reported L2 use: The Japanese ESL context. Second Language Studies, 20(2):29-70.

Khatibi, M. B., \& Zakeri, J. (2014). Iranian EFL learners' willingness to communicate across different context- and receiver-types. Procedia - Social and Behavioral Sciences, 98, 932-939. https://doi. org/10.1016/j.sbspro.2014.03.502

Kim, S. J. (2004). Exploring willingness to communicate (WTC) in English among Korean EFL students in Korea: WTC as a predictor of success in second language acquisition. Unpublished PhD thesis, Ohio State University. http://rave.ohiolink. edu/etdc/view?acc_num=osul101267838

Macintyre, P. D. \& Charos, C. (1996). Personality, attitudes, and affect as predictors of second language communication. Journal of Language and Social Psychology, 15(1), 3-26. https://doi. org/10.1177/0261927X960151001

Maclntyre, P. D. (1994). Variables underlying willingness to communicate: a causal analysis. Communication Research Reports, 11, 135-142. https://doi.org/10.1080/08824099409359951

Macintyre, P. D., Baker, S. C., Clément, R., \& Conrod, S. (2001). Willingness to communicate, social support, and language learning orientations of immersion students. Studies in Second Language Acquisition, 23, 369-388. https://doi. org/10.1177/0261927X03022002003

Maclntyre, P. D., Dörnyei, Z., Clément, R., \& Noels, K. A. (1998). Conceptualizing willingness to communicate in a L2: Situational model of L2 confidence and affiliation. The Modern Language Journal, 82(4), 545-562. https://doi.org/10.1111/j.1540-4781.1998. tb05543.x

Mašić A., Polz, E. \& Bećirovic, S., (2020) The Relationship between Learning Styles, GPA, School Level and Gender. European Researcher. Series A, 11(1), 51-60. doi: 10.13187/er.2020.1.51

McCroskey, J. C. (1992). Reliability and validity of the willingness to communicate scale. Communication Quarterly, 40(1), 16-25. https://doi. org/10.1080/01463379209369817

McCroskey, J. C. (2001). An introduction to rhetorical communication. Boston, MA: Allyn \& Bacon, 40 .

McCroskey, J. C., \& Baer, J. E. (1985). Willingness to communicate: The construct and its measurement. Paper presented at the annual convention of the Speech Communication Association, Denver, Colorado.

Modirkhameneh, S., \& Firouzmand, A. (2014). Iranian EFL learners' willingness to communicate and language learning orientations. Procedia - Social and Behavioral Sciences, 98, 1134-1139. https:// doi.org/10.1016/j.sbspro.2014.03.526 


\section{Gocial Geiences \\ by MAP - Multidisciplinary Academic Publishing \\ TO SPEAK OR NOT TO SPEAK? THEORETICAL FRAMEWORK OF WILLINGNESS TO COMMUNICATE \\ Emina Kahrimanović}

Mystkowska-Wiertelak, A., \& Pawlak, M. (2016). Designing a tool for measuring the interrelationships between L2 WTC, confidence, beliefs, motivation, and context. Second Language Learning and Teaching, 19-37. doi:10.1007/978-3-319-303734_2

Noon-ura, S. (2008). Teaching listening speaking skills to Thai students with low English proficiency. Asian EFL journal, 10(4), 173-192.

Pattapong, K. (2010). Willingness to communicate in a second language: A qualitative study of issues affecting Thai EFL learners from students' and teachers' point of view. Unpublished doctoral dissertation. The University of Sydney, Sydney, New South Wales.

Peng, J. E. (2007). Willingness to communicate in an L2 and integrative motivation among college students in an intensive English language program in China. University of Sydney Papers in TESOL, 2, 33-59.

Richards, J.C. and Schmidt, R. (2002). Longman Dictionary of Language Teaching \& Applied Linguistics (3rd edition). Essex: Pearson Education Limited.

Rizvić E., \& Bećirović, S., (2017). Willingness to Communicate in English as a Foreign Language in Bosnian-Herzegovinian EFL Context. European Researcher, 8(3), 224-235. doi: 10.13187/er.2017.3.224

Sinanović, J., \& Bećirović S. (2016). The Determinants of Lifelong Learning. European researcher, 103(2), 107-118. doi: 10.13187/er.2016.103.107

Tremblay, P. F., \& Gardner, R. C. (1995). Expanding the motivation construct in language learning. The Modern Language Journal, 79, 505518. https://doi.org/10.2307/330002

Warner, E. D. (1997). A description of the approaches to communication apprehension. Communication Theses, 6. Retrieved from https://digitalcommons.brockport.edu/cmc_theses/6

Yaman, A. \& Bećirović, S. (2016). Learning English and Media Literacy. Imperial Journal of Interdisciplinary Research (IJIR), 2(6), 660-663. 